\title{
Trace Elemental Expression in Soil Substratum and Floral Species in Selected Lateritic Profiles in the Northern Part of Kolar Schist Belt, Dharwar Craton, India
}

\author{
B. C. Prabhakar ${ }^{1}$, B. N. Rashmi' ${ }^{2}$, R. V. Gireesh ${ }^{3}$ \\ ${ }^{1}$ Department of Geology, Bangalore University, Bangalore, India \\ ${ }^{2}$ Karnataka State Natural Disaster Monitoring Centre, Bangalore, India \\ ${ }^{3}$ School of Earth Sciences, Central University of Karnataka, Kalaburagi, India \\ Email: bcprabhakar@rediffmail.com
}

How to cite this paper: Prabhakar, B.C., Rashmi, B.N. and Gireesh, R.V. (2017) Trace Elemental Expression in Soil Substratum and Floral Species in Selected Lateritic Profiles in the Northern Part of Kolar Schist Belt, Dharwar Craton, India. International Journal of Geosciences, $\mathbf{8}$, 1004-1024.

https://doi.org/10.4236/ijg.2017.88057

Received: February 18, 2017

Accepted: August 25, 2017

Published: August 28, 2017

Copyright $\odot 2017$ by authors and Scientific Research Publishing Inc. This work is licensed under the Creative Commons Attribution International License (CC BY 4.0).

http://creativecommons.org/licenses/by/4.0/

\section{(c) (i) Open Access}

\begin{abstract}
Extensive laterite cappings are observed in the northern part of Kolar schist belt and they are underlain by pillowed metabasalt and partially weathered auriferous cherty intercalations. To appraise the possible distribution of trace elements in both laterite cappings and in plants growing over there, a geobotanical study was conducted in the well exposed, almost flat to slightly undulating lateritic profiles in Jaderi-Holur-Nayakarahalli stretch in the northern part of Kolar schist belt. Due to humus-poor lateritic soil and scanty rainfall, the vegetation is sparse and scrubby. Shrub species are relatively more abundant than herbs and trees. The shrub species studied are Argyreia cuneata, Dodonaea viscosa, Carissa carandas, Ziziphus species, Barleria buxifolia and Atylosia scarbiocides. The herb species are mainly represented by Leucas ciliata, Pulicaria wightiana, Hyptis suaveolens, Tephrosia tinctoria, Trichodesma indicum, Stylosanthes fruticosa, Evolvulus alsinoides, Pavonia zeylanica, Orthosiphon diffusus, Waltheria indica and Stachytarpheta indica. Less frequent species included Acacia megaladena and Dolichandrone atrovirens. Geochemical analysis of different plant species and lateritic soil samples has been carried out. $\mathrm{Cu}, \mathrm{Cr}, \mathrm{Zn}, \mathrm{Ni}, \mathrm{Co}, \mathrm{As}$ and $\mathrm{Mn}$ are in good concentration in soil but the same, except $\mathrm{Mn}$, are impoverished in the plant species. A few analyses for $\mathrm{Au}$ show that its values are close to background concentration. However, plant uptake of $\mathrm{Au}$ appears to be better ( $25-86 \mathrm{ppb})$. The humic acid activity could have enabled gold to get absorbed by plants. While all other analyzed metals show higher range of concentration in soil compared to flora, gold shows a reverse relationship.
\end{abstract}




\section{Keywords}

Kolar Schist Belt, Biogeochemistry, Lateritic Profiles, Soil Geochemistry

\section{Introduction}

The study area (Figure 1) forms a part of the Kolar schist belt which is/was

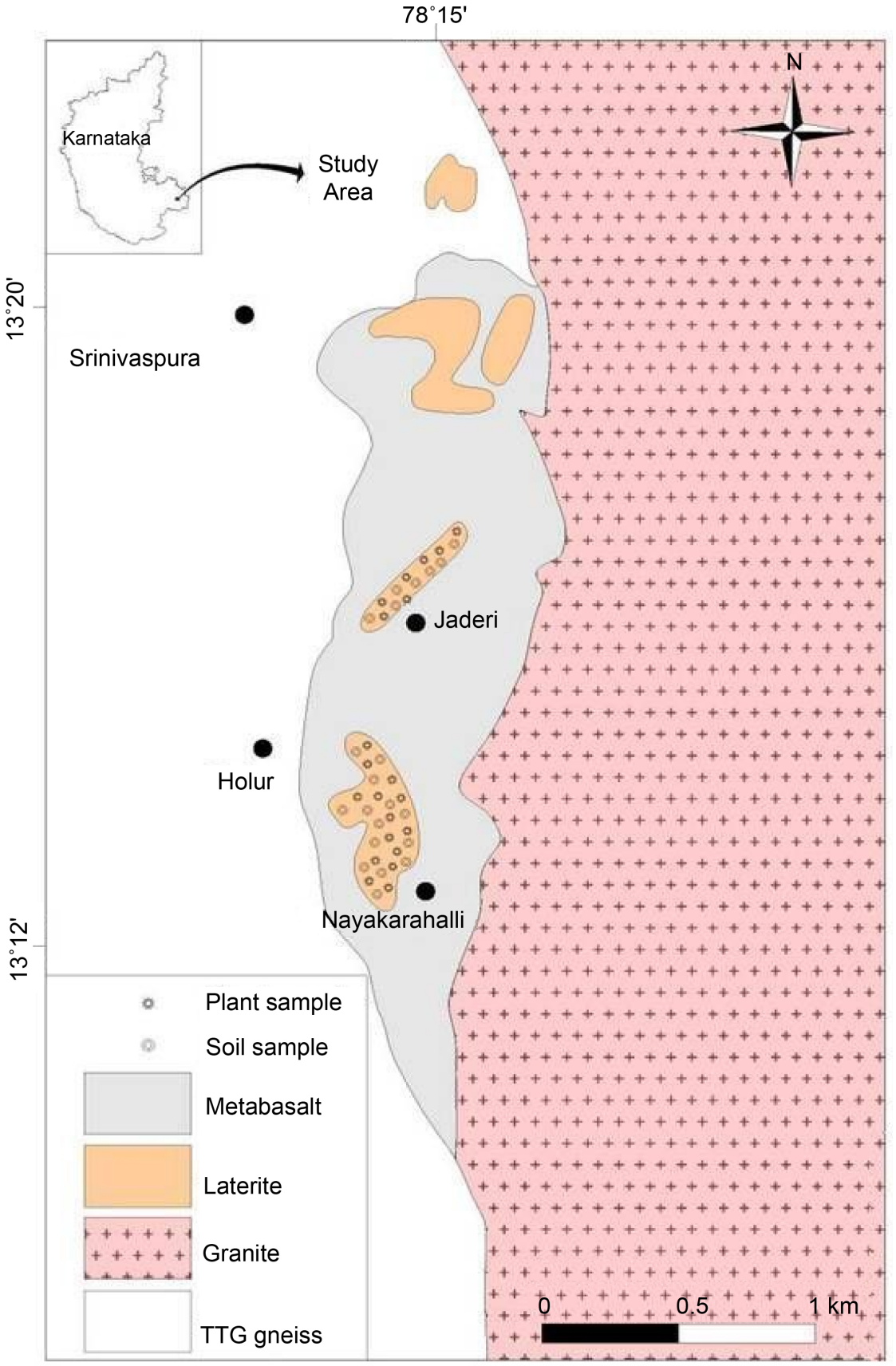

Figure 1. Geological sketch map of part of Kolar Schist belt showing plant and soil sample locations. 
known for its world class lode gold deposits which are now almost exhausted due to continuous mining for over 100 years. This auriferous belt is made up of abundant metavolcanic sequences and thin metasedimentary intercalations of BIF. The BIF is chiefly confined to western boundary of the belt. Few ultramafic sequences have also been found to be present in this belt. The gold bearing lodes were mainly in the form of quartz-carbonate veins with commonly noticed sulphides like pyrite, pyrrhotite and arsenopyrite in the mineralized blocks. Carbonaceous schist horizons are found to be in close proximity with the gold bearing veins. Studies by Sivasiddaih and Rajamani [1], Narayanswamy et al. [2] and Mukherjee, [3] provided lithological, structural and genetic aspects of Au mineralization in Kolar schist belt. The northern part of this belt, especially south of Srinivaspura, has been extensively lateritised (Figure 2) and the lateritic profiles appear as flat to undulatory features. The topography is by and large smooth with weathered bedrocks of pillowed (Figure 3) metavolcanics, sometimes exposed along nala cuts. Highly weathered lateritic areas in some places display cavernous structures (Figure 4), especially south of Nayakarahalli. River streams have low gradient and have dissected this country to produce shallow ravines. Several field traverses in the above said tracts revealed the presence of partially weathered sulphidic cherty layers (Figure 5) within the lateritized metabasaltic bedrocks. Lateritic soil and the enclosed cherty bands are drained by streams and the stream-sediments are panned by locals to extract gold fines/nuggets. This aptly reflects the auriferous nature of cherty BIF-bearing metavocanics in the studied area. The insitu enrichment of gold in laterites is also reported elsewhere, especially from Nilambur [4] and Chinmulgund [5] areas. The pillowed nature of basaltic rocks which are frequently traversed by sulphidic cherty veins, and moderate to strong lateritization is good indications to infer that Au could be distributed in the weathered substratum/soil in the study area. Also, the

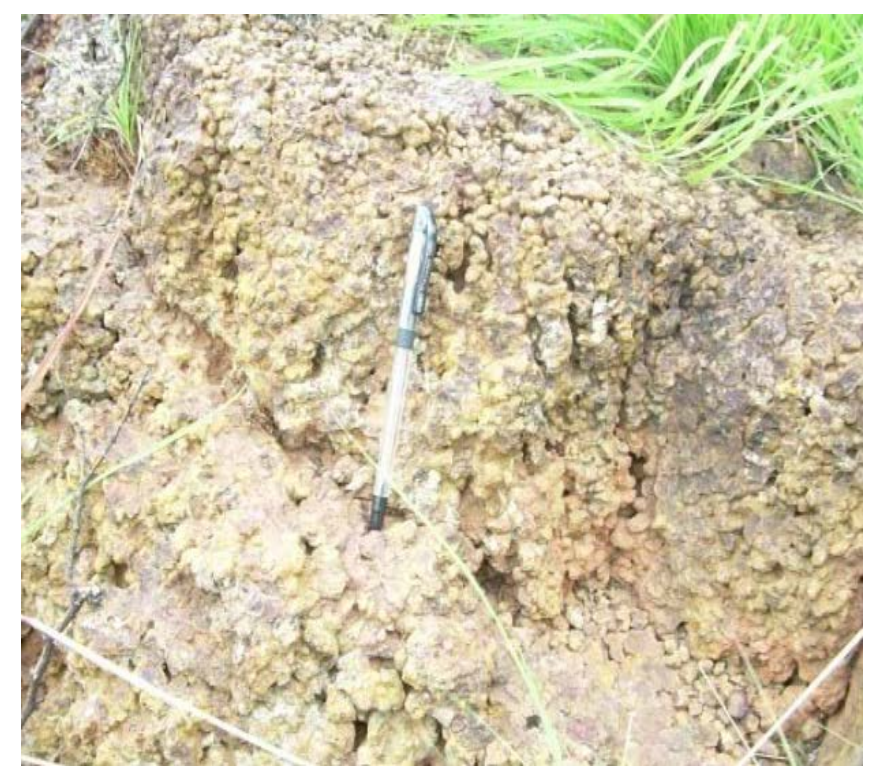

Figure 2. Lateritised metabasalt, south of Srinivasapura. 


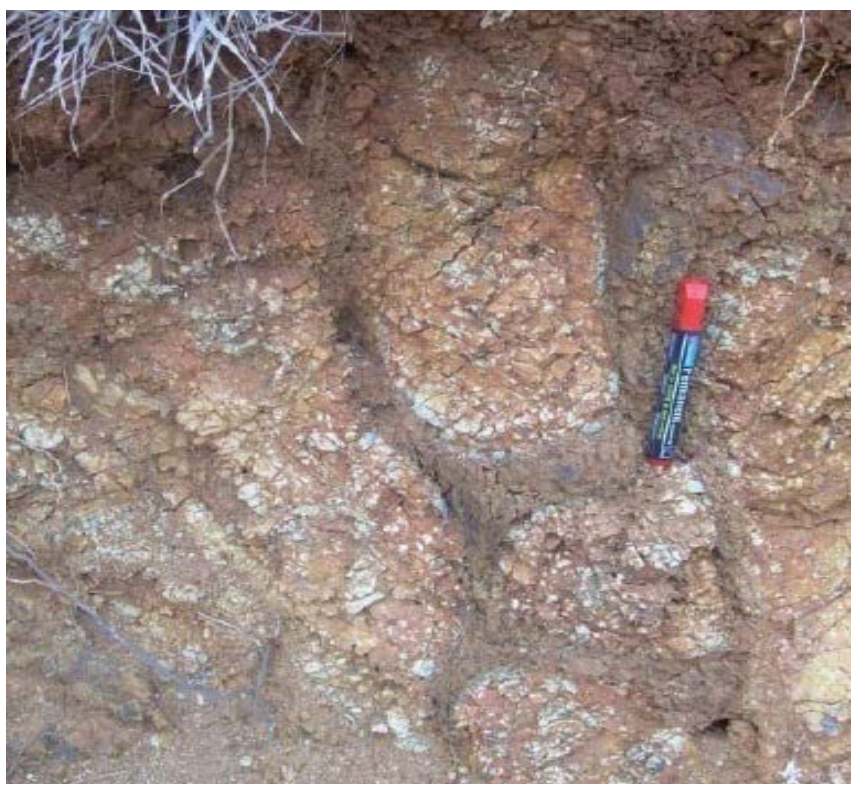

Figure 3. Partially weathered pillowed metabasalt near Nayakarahalli.

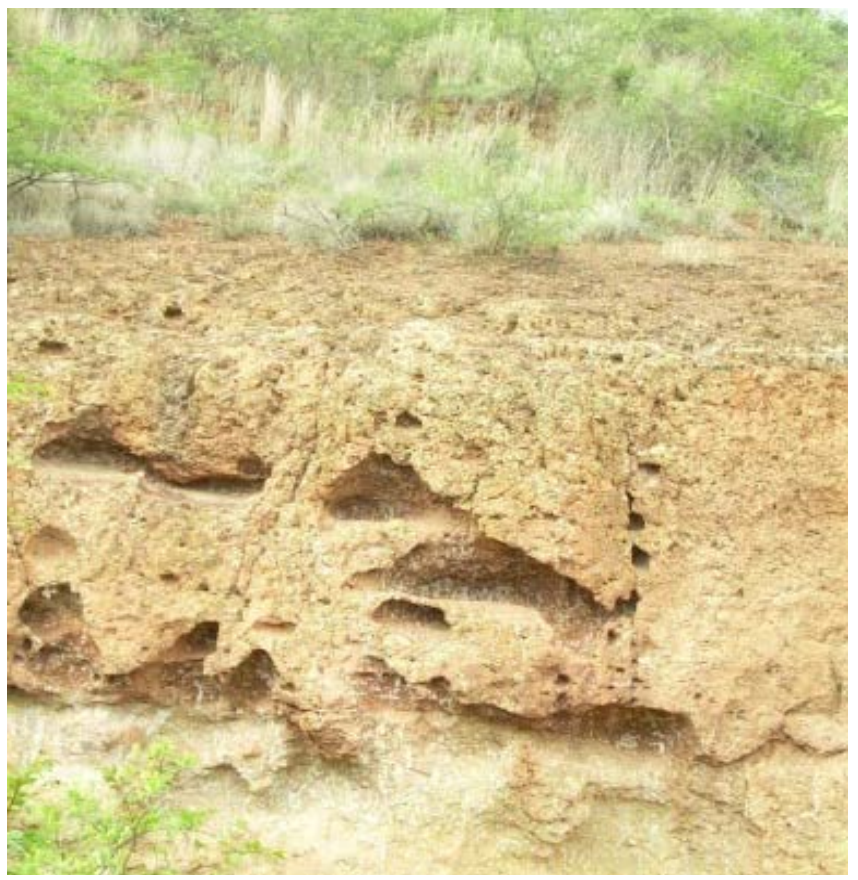

Figure 4. Cavernous structures in lateritic zones near Nayakarahalli.

plants which grow in this area, could have possibly up-taken gold, besides other metals, during their metabolic activity. In this background, the areas near Nayakarahalli, Jaderi, and Holur, south of Srinivasapura where lateritic profiles are well developed, though discontinuously, have been subjected for geobotanical and biogeochemical studies with the main objective of understanding metal concentration, especially gold, in plants and soil. 


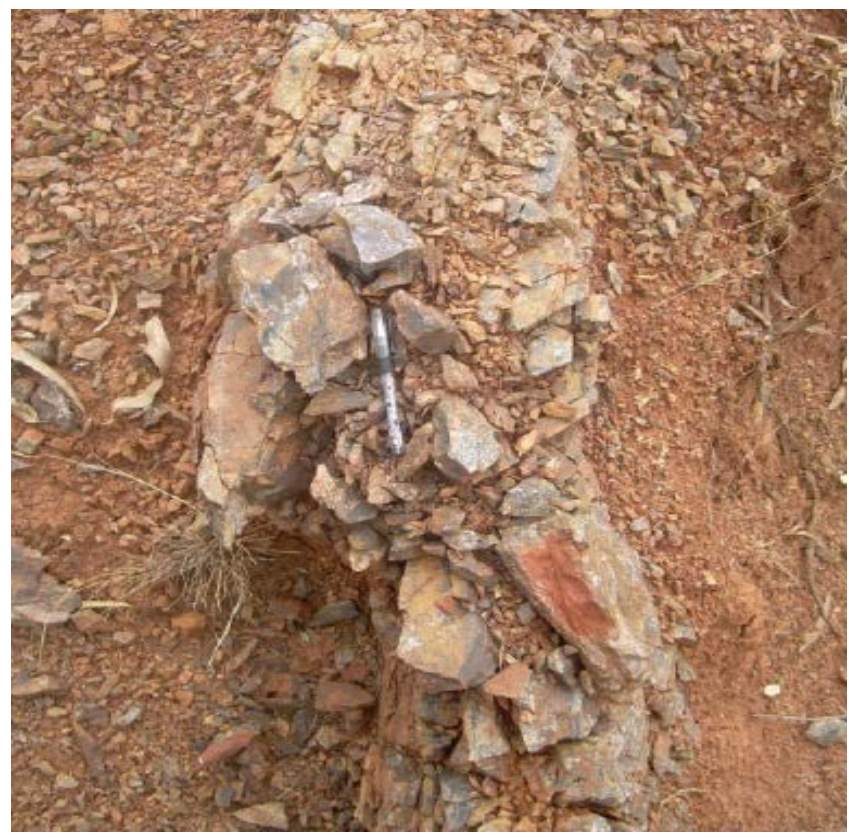

Figure 5. Weathered Cherty layer within the lateratised metabasalt near Nayakarahalli.

\section{Sampling Method}

A cursory study of the terrain was made before samples were collected. The procedure, as enumerated by Brooks [6] was followed during plant sampling. The density and homogeneity of different species were appraised to minimize sampling errors. The soil substratum was also checked for possible human contamination, since it has proximity to mining area. Field work and sampling were carried out during post monsoon time in the month of November. This was the time when most of the herb and shrub species showed their full blooming. Precaution was taken to complete the sampling work in minimum time to ensure the least climatic influence on elemental uptake by plants. A rectangular grid sampling pattern was followed for sampling. The density and homogeneity of vegetation was thoroughly evaluated before sampling. Precautions like sampling the same species of plants, sampling the same organs of plants, recognizing the same growth level of plants and similar appearance and health of the plants were kept in mind while sampling [7]. At selected points soil samples were also collected to correlate their trace element values with plant samples. Care was also taken to observe any visible signs of morphological anomalies in plant species.

\section{Analytical Method}

The dried and pulverized samples of plants were decomposed by hot acid treatment. 0.5 g plant sample was digested using $0.5 \mathrm{ml}$ con. $\mathrm{H}_{2} \mathrm{O}_{2}$ and $4 \mathrm{ml}$ con. $\mathrm{HNO}_{3}$ in a tefflon digestion vessel in a microwave digester for 20 minutes.

The soil samples were also digested in microwave digester. Firstly, they were 
ground to -200 mesh by jaw crusher and further fine-ground to -250 mesh by agate mortar. Coning and quartering were done prior to taking required amount of sample. $0.25 \mathrm{gm}$ of soil sample was digested with $2.5 \mathrm{ml}$ of $\mathrm{HF}$ and $2.5 \mathrm{ml}$ of con. $\mathrm{HNO}_{3}$ using Teflon digestion vessel in the microwave digester for $25 \mathrm{mi}-$ nutes. After digestion they were filtered by Whatman's No. 42 filter paper and made up to $100 \mathrm{ml}$ and used as stock solutions. Subsequently they (both plant and soil samples) were analysed by AAS (GBC make). Merck AAS standards were used for calibration. Repeat analyses were done at five sample interval for accuracy and precision. The above mentioned method was used for analysis of $\mathrm{Cu}, \mathrm{Cr}, \mathrm{Zn}, \mathrm{Ni}, \mathrm{Co}, \mathrm{As}, \mathrm{Mn}$ and $\mathrm{Mg}$. The results of the analyses for plant samples are listed in Table 1 and that of soil samples in Table 2.

However, for $\mathrm{Au}$ analysis, the pulverized plant and soil samples were ignited at $700^{\circ} \mathrm{C}$ for $1-2$ hours with aquarigia solution, twice followed by $\mathrm{HCl}$ solution. For this $5 \mathrm{ml}$ MIBK (methyl iso butyl ketone) was added and shaken for $5 \mathrm{mi}$ nutes. The organic layer was washed with $10 \mathrm{ml} 0.6 \mathrm{~N} \mathrm{HCl}$ and this organic layer was collected in a dry $10 \mathrm{ml}$ flask and was subjected for gold analysis using GFAAS (Graphite Furnace-Atomic Absorption Spectrometer) along with standards which were also extracted in MIBK and the unknown concentration of $\mathrm{Au}$ in samples were determined.

\subsection{Vegetation Pattern}

The studied area is moderately vegetated. It exhibits scrubby to semi-deciduous type vegetation. Though, the soil substratum is fairly well developed, vegetation growth is not dense, probably due to poor humus content and hard pan-like nature of lateritic substratum at many places and modest rainfall (annual around $700 \mathrm{~mm}$ ). Another possible reason for poor vegetation could be the removal of essential nutrients during the lateritization process [6]. However, in valley portions and moderately lateritized metabasaltic areas, vegetation is fairly denser. The dominant plant species in the study area are shrubs followed by herbs with less frequency of tree species. The shrub species are mainly represented by $A r$ gyreia cuneata, Dodonaea viscosa, Carissa carandas, Ziziphus, Barleria buxifolia, and Atylosia scarbiocides and the herb species by Leucas ciliata, Pulicaria wightiana, Chromolaena odorata, Hyptis suaveolens, Tephrosia tinctoria, Trichodesma indicum, Stylosanthes fruticosa, Evoluvus alsinoides, Pavonia zeylanica, Orthosiphon diffusus, Waltheria indica and Stachytarpheta indica. Fairly good distribution of Grass species (lemon grass) is also observed but is normally found in areas of deep soil cover. The common tree species noticed is Acacia megaladena. Another sparsely distributed tree species is Dolichandrone atrovirens.

In the present study, sampling of plants and soil has been carried out in 3 blocks, viz, Nayakarahalli, Holur and Jaderi. All these 3 blocks, as mentioned earlier, are mostly characterized by lateritic soil, with a scrubby vegetation pattern. The soil surface is normally characterized by the presence of sub-rounded (resembling nodular) iron rich gravels. The sampling was carried out during 
Table 1. Trace Element concentrations (in ppm) in plant species of study area.

\begin{tabular}{|c|c|c|c|c|c|c|c|}
\hline Sample no. & $\mathrm{Cu}$ & $\mathrm{Cr}$ & $\mathrm{Zn}$ & $\mathrm{Ni}$ & Co & As & Mn \\
\hline \multicolumn{8}{|c|}{ Leucas ciliata } \\
\hline $\mathrm{N} 2$ & 120 & 55.24 & 39.6 & 14 & 25 & 19 & 1639.58 \\
\hline N5 & 110 & 75.64 & 33.82 & 25 & 62 & & 818.76 \\
\hline N9 & 90 & 107.7 & 15.52 & 18 & 18 & 51 & 1116.2 \\
\hline $\mathrm{N} 23$ & 135 & 14.9 & 51.86 & 20 & - & 12 & 2203.22 \\
\hline N39 & 65 & 93.16 & 8.18 & - & 33 & 41 & 1205.64 \\
\hline $\mathrm{N} 42$ & 105 & 203.16 & 131.14 & 45 & - & 62 & 5513.84 \\
\hline N45 & - & 161.98 & 74.66 & - & 41 & - & 1122.72 \\
\hline $\mathrm{N} 48$ & 90 & 44.54 & 26.24 & 65 & 45 & 10 & 1982.08 \\
\hline J5 & 160 & 110.32 & 77.68 & 30 & - & 33 & 1778 \\
\hline J7 & - & 67.44 & 23.22 & 18 & 64 & 27 & 1767.92 \\
\hline H9 & 110 & 36.3 & 81.68 & 15 & 42 & 28 & 998.2 \\
\hline Average & 110 & 88.22 & 51.24 & 27.78 & 41.25 & 31.44 & 1831.47 \\
\hline \multicolumn{8}{|c|}{ Dodonaea viscosa } \\
\hline N3 & 150 & 87.18 & 136.7 & 25 & 22 & 52 & 924.82 \\
\hline 14 & 180 & 19.24 & 102.9 & 85 & 23 & 58 & 858.2 \\
\hline 22 & - & 15.32 & 75.66 & 120 & 34 & 42 & 1241.94 \\
\hline 27 & 130 & 8.98 & 73.08 & 160 & - & 49 & 1102.88 \\
\hline 50 & 105 & 24.44 & 102.24 & 170 & 35 & 54 & 862.48 \\
\hline $\mathrm{H} 2$ & 110 & 82.14 & 149.06 & 170 & - & 63 & 765.3 \\
\hline 4 & 120 & 64.96 & 73.5 & 105 & 10 & 41 & 869.48 \\
\hline Average & 116.25 & 43.18 & 101.88 & 119.29 & 24.80 & 51.29 & 946.44 \\
\hline \multicolumn{8}{|c|}{ Acacia megaladena } \\
\hline N6 & 65 & 93.7 & 64.3 & 105 & 45 & 23 & 304.62 \\
\hline 29 & 95 & 91.28 & & 25 & - & 34 & 304.12 \\
\hline 36 & - & 109.3 & 71.9 & 10 & 33 & 49 & 7879.78 \\
\hline 37 & 100 & 89.34 & - & 75 & - & 15 & 292.54 \\
\hline $\mathrm{H} 1$ & 110 & 33.61 & - & 10 & 30 & 28 & 529.78 \\
\hline 6 & 95 & 76.96 & - & 20 & 72 & 63 & 428.76 \\
\hline Average & 101.67 & 82.365 & 68.1 & 40.83 & 45 & 35.33 & 1623.267 \\
\hline \multicolumn{8}{|c|}{ Argyreia cuneata } \\
\hline N7 & 100 & 76.6 & 59.8 & 30 & 18 & 24 & 1048.12 \\
\hline 31 & 85 & 51.34 & & 40 & 20 & 28 & 1859.4 \\
\hline Average & 92.5 & 63.97 & 59.8 & 35 & 19 & 26 & 1453.76 \\
\hline \multicolumn{8}{|c|}{ Grass } \\
\hline$N 12$ & 65 & 105.02 & 54.3 & 45 & 31 & 1 & 6064.84 \\
\hline
\end{tabular}


B. C. Prabhakar et al.

\section{Continued}

\begin{tabular}{|c|c|c|c|c|c|c|c|}
\hline 16 & 50 & 32.5 & 42.6 & 25 & 42 & 3 & 2767.66 \\
\hline 32 & - & 225.78 & & 60 & - & - & 952.14 \\
\hline 40 & 80 & 96.02 & 34.78 & 50 & 10 & 5 & 3873.22 \\
\hline Average & 65 & 114.83 & 43.89333 & 45.00 & 27.67 & 3 & 3414.465 \\
\hline \multicolumn{8}{|c|}{ Carissa carandus } \\
\hline$N 13$ & 120 & 56.4 & 70.54 & 16 & 32 & 20 & $11,335.52$ \\
\hline 15 & 130 & 49.28 & 85.94 & 22 & - & 31 & 3875.18 \\
\hline 30 & 110 & 73.84 & 83.84 & 18 & 58 & 37 & 1123.6 \\
\hline 38 & 105 & 26.6 & 133.14 & 10 & - & 42 & 1638.1 \\
\hline $\mathrm{H} 7$ & - & 33.88 & 98.42 & 25 & 20 & 58 & 3901.36 \\
\hline Average & 116.25 & 48 & 94.376 & 18.2 & 36.66667 & 37.6 & 4374.752 \\
\hline \multicolumn{8}{|c|}{ Tephrosia tinctoria } \\
\hline N17 & 130 & 47.12 & 38.3 & 25 & 28 & 16 & 2922.1 \\
\hline 24 & 180 & 35.74 & 42.1 & 23 & 32 & 6 & 1920.3 \\
\hline 26 & 90 & 37.58 & - & 18 & 10 & 34 & 2400.7 \\
\hline 34 & - & 27.26 & - & 24 & 14 & 44 & 1670.12 \\
\hline $\mathrm{J} 8$ & 160 & 30.2 & - & 16 & 16 & 19 & 1315.62 \\
\hline 9 & 145 & 51.12 & 0.76 & 21 & 18 & 25 & 1344.86 \\
\hline Average & 141 & 38.17 & 27.05 & 21.167 & 19.67 & 24 & 1928.95 \\
\hline \multicolumn{8}{|c|}{ Barleria buxifolia } \\
\hline $\mathrm{N} 20$ & 40 & 56.08 & & 44 & 12 & 8 & 538.22 \\
\hline 21 & 120 & 7.82 & 66.52 & 40 & 14 & - & 451.36 \\
\hline 25 & - & 30.2 & 39.4 & 38 & - & 3 & 1750.18 \\
\hline $\mathrm{J} 10$ & 95 & 52.02 & - & 12 & - & 7 & 608.66 \\
\hline 16 & - & 63.02 & 114.94 & 22 & 10 & 4 & 565.28 \\
\hline H5 & 150 & 86.24 & - & 16 & 33 & 8 & 9403.56 \\
\hline Average & 101.25 & 49.23 & 73.62 & 28.67 & 17.25 & 6 & 2219.54 \\
\hline \multicolumn{8}{|c|}{ Ziziphus species } \\
\hline N18 & 110 & 78.18 & 112.2 & 14 & 12 & 15 & $14,576.94$ \\
\hline h3 & 90 & 115.26 & 120.4 & 58 & - & 27 & 8116.16 \\
\hline $\mathrm{H} 8$ & 35 & 92.4 & 191.36 & 62 & 16 & 34 & $17,271.48$ \\
\hline Average & 78.33 & 95.28 & 141.32 & 44.67 & 14.00 & 25.3333 & $13,321.53$ \\
\hline \multicolumn{8}{|c|}{ Waltheria indica } \\
\hline N44 & 20 & 83.98 & 15.02 & 33 & 20 & 23 & 3009.28 \\
\hline $\mathrm{J} 15$ & - & 34.24 & 338.7 & 42 & 12 & 13 & 1152.34 \\
\hline H11 & 130 & 86.04 & 95.76 & 15 & - & 18 & 3240 \\
\hline Average & 75 & 68.09 & 149.83 & 30 & 16 & 18.00 & 2467.21 \\
\hline
\end{tabular}




\section{Continued}

\begin{tabular}{|c|c|c|c|c|c|c|c|}
\hline \multicolumn{8}{|c|}{ Atylosia scarbiocides } \\
\hline N46 & 140 & 132.48 & - & 45 & 13 & & 1688.62 \\
\hline $\mathrm{J} 4$ & 120 & 78.3 & 569.16 & 10 & 10 & 6 & 2992.3 \\
\hline Average & 130 & 105.39 & 569.16 & 27.5 & 11.5 & 6 & 2340.46 \\
\hline \multicolumn{8}{|c|}{ Evolvulus alsinoides } \\
\hline $\mathrm{J} 2$ & 120 & 209.24 & 156.08 & 5 & 17 & 8 & 1278.22 \\
\hline \multicolumn{8}{|c|}{ Stylosanthes fruticosa } \\
\hline $\mathrm{J} 3$ & 190 & 133.86 & 203.76 & 25 & 21 & 4 & 2522.4 \\
\hline \multicolumn{8}{|c|}{ Pulicaria wightiana } \\
\hline $\mathrm{H} 10$ & 76.7 & 368.26 & 262.56 & 13 & 20 & 10 & 3308.24 \\
\hline \multicolumn{8}{|c|}{ Pavonia zeylanica } \\
\hline N51 & 90 & 35.38 & 576.58 & 18 & 24 & 21 & 2185.23 \\
\hline $\mathrm{J} 13$ & 100 & 74.76 & 131.02 & 16 & 13 & 6 & 2729.04 \\
\hline Average & 95 & 55.07 & 353.8 & 17 & 18.5 & 13.5 & 2457.135 \\
\hline \multicolumn{8}{|c|}{ Stachytarpheta indica } \\
\hline $\mathrm{J} 14$ & 175 & 41.6 & 57.28 & 14 & 12 & 3 & 963.34 \\
\hline \multicolumn{8}{|c|}{ Orthosiphon diffusus } \\
\hline N49 & - & 116.34 & 156.68 & 35 & 15 & 4 & 1635.36 \\
\hline \multicolumn{8}{|c|}{ Trichodesma indicum } \\
\hline $\mathrm{J} 12$ & 5.08 & 213.66 & 355.2 & 48 & 16 & 22 & 1996.32 \\
\hline N28 & - & 19.1 & & 64 & 10 & 21.5 & 2904.38 \\
\hline N11 & 130 & 134.7 & 530.72 & - & - & 24 & 2078.52 \\
\hline Average & 67.54 & 122.4867 & 442.96 & 56 & 13 & 22.5 & 2326.407 \\
\hline \multicolumn{8}{|c|}{ Hyptis suaveolens } \\
\hline $\mathrm{J} 1$ & 140 & 26.64 & - & 34 & 20 & 13 & 2802.8 \\
\hline $\mathrm{J} 11$ & 135 & 45.34 & 223.02 & 30 & 17 & 18 & 1675.2 \\
\hline Average & 137.5 & 35.99 & 223.02 & 32 & 18.5 & 15.5 & 2239 \\
\hline
\end{tabular}

November period, when both herbs and shrubs were showing their exuberance and obviously it reflected the optimal metal uptake possibilities. Due to the absence of specific mineralized zone, sampling was done with roughly rectangular grid pattern with more or less the same distance from one sampling spot to other. Though small outcrops of cherty reefs are observed, their continuity could not be traced, owing to weathering effects. Thus, the entire laterite ground had to be targeted for geobotanical study and sample collection. A brief description of plant species studied and sampled and their biogeochemical aspects have been provided below. 
Table 2. Trace element concentration (in ppm) in soil samples.

\begin{tabular}{|c|c|c|c|c|c|c|c|c|c|}
\hline \multicolumn{10}{|c|}{ Soils } \\
\hline Sample no. & $\mathrm{Cu}$ & $\mathrm{Cr}$ & $\mathrm{Zn}$ & $\mathrm{Ni}$ & Co & As & $\mathrm{Mn}$ & $\mathrm{Mg}$ & $\mathrm{pH}$ \\
\hline \multicolumn{10}{|c|}{ Nayakarahalli } \\
\hline N1 & 4593 & 7929 & - & 2235 & 309 & 65 & 3975 & 10,285 & 8.04 \\
\hline 2 & - & - & 204 & - & 136 & 80 & 2345.8 & 1328 & 8.06 \\
\hline 3 & 2328 & 3038 & & 1622 & 188 & 12 & 29,806 & 5559 & 8.08 \\
\hline 5 & 342 & 1386 & 20 & 228 & - & 30 & 1193 & 2916 & 7.07 \\
\hline $6 a$ & 1864 & 4157 & 827 & 1502 & 299 & 20 & 30,510 & 5941 & 8.24 \\
\hline $6 \mathrm{~b}$ & 1219 & 1406 & 492 & 717 & - & 16 & 9445 & 1518 & 8.21 \\
\hline 7 & 2917 & 5015 & 409 & 1673 & 329 & 52 & 3765 & 1452 & 8.25 \\
\hline 8 & 1692 & 4032 & 682 & 1067 & 162 & 25 & 15,563 & 5633 & 7.84 \\
\hline 9 & 630 & 1584 & 366 & 930 & 154 & 56 & 11,663 & 2404 & 7.3 \\
\hline 10 & 2252 & 4968 & 1023 & 1820 & 599 & 42 & 6163 & 7324 & 7.21 \\
\hline 11 & 986 & 2819 & 154 & 1366 & 637 & 52 & 13,316 & 6478 & 7.19 \\
\hline 12 & 972 & 2942 & 206 & 1403 & 376 & 57 & 6098 & 5632 & 6.52 \\
\hline 13 & 1233 & 3558 & 169 & 716 & 172 & 35 & 16,611 & 6386 & 7.42 \\
\hline 14 & 2257 & 3310 & 36 & 1071 & 583 & 62 & 3595 & 6328 & 8.25 \\
\hline 15 & 2143 & 4120 & & 964 & 261 & 18 & 13,846 & 8188 & 6.81 \\
\hline 16 & 62 & 1461 & 83 & 453 & 84 & 29 & 1951 & 2615 & 6.5 \\
\hline 17 & 238 & 1197 & 181 & 271 & - & 45 & 2543 & 2991 & 5.37 \\
\hline 18 & 97 & 1177 & 64 & 478 & - & 36 & 2410 & 2809 & 6.66 \\
\hline 19 & 227 & - & - & 615 & - & 32 & 2586 & 3398 & 6.74 \\
\hline 20 & 1024 & 1909 & - & 1142 & - & 11 & 22,313 & 1782 & 6.85 \\
\hline 21 & 2600 & 5399 & 212 & 932 & - & 104 & 39,663 & 9051 & 6.46 \\
\hline 22 & 1508 & 4296 & - & 1012 & 398 & 74 & 5839 & 5624 & 6.6 \\
\hline 23 & 315 & 1546 & 87 & 525 & 38 & 15 & 892 & 3280 & 6.27 \\
\hline 24 & 1411 & 3906 & 933 & 931 & 463 & 18 & 120,749 & - & 7.53 \\
\hline 25 & 2993 & 5880 & 585 & 1952 & 530 & 26 & 86,758 & 7179 & 7.84 \\
\hline 26 & 864 & 2453 & 161 & 884 & 29 & 49 & 9681 & 1897 & 8.07 \\
\hline 27 & 717 & 1413 & 25 & 363 & - & 52 & 3091 & 4244 & 6.4 \\
\hline 28 & 1697 & 2801 & 380 & 1034 & 142 & 73 & 7972 & 6945 & 6.52 \\
\hline 29 & 630 & 2650 & 98 & 827 & - & 62 & 1525 & 2829 & 5.99 \\
\hline 30 & 1581 & 2322 & 244 & 649 & 311 & 50 & 6924 & 9396 & 6.88 \\
\hline Average & 1427 & 3167 & 318 & 1013 & 295 & 43 & 16,567 & 4876 & 7.17 \\
\hline \multicolumn{10}{|c|}{ Jaderi } \\
\hline $\mathrm{J} 1$ & 734 & 2025 & 111 & 1828 & 688 & 35 & 6661 & 5665 & 7.4 \\
\hline $\mathrm{J} 2$ & 1493 & 1481 & 640 & 2749 & 811 & 120 & 11,315 & 1854 & 7.12 \\
\hline
\end{tabular}


Continued

\begin{tabular}{cccccccccc}
\hline J3 & 1038 & 1571 & 29 & 1677 & 1106 & 142 & 9111 & 13,875 & 6.55 \\
J4 & 581 & 1581 & 93 & 1340 & 179 & 58 & 7412 & 4243 & 6.6 \\
J5 & 1674 & 6892 & 34 & 2702 & 1279 & 35 & 36,499 & 16,549 & 7.49 \\
J6A & 1359 & 3573 & 318 & 2667 & 884 & 46 & 11,868 & 6792 & 7.67 \\
J6B & 800 & 2073 & 131 & 1875 & 784 & 52 & 9519 & 6629 & 8.09 \\
J7A & 757 & 2235 & 122 & 1220 & 258 & 38 & 17,715 & 4970 & 7.78 \\
J7B & 698 & 1846 & 151 & 1481 & - & 65 & 4956 & 1256 & 6.91 \\
J8 & 610 & 3375 & - & 1171 & 568 & 57 & 11,365 & 7259 & 7.14 \\
HS1 & - & - & 96 & - & - & 67 & - & 1259 & 7.24 \\
HS2 & 693 & - & 84 & 1167 & - & 53 & - & 1552 & 7.44 \\
Average & 949 & 2665 & 164 & 1807 & $\mathbf{7 2 8}$ & 64 & 12642 & 5992 & 7.29 \\
\hline
\end{tabular}

\subsection{Leucas ciliata}

It is one of the most common herbs in the lateritic zones of Nayakarahalli. It is a small herb with long and slender leaves. It has more or less a uniform distribution and is fairly denser in occurrence. Eleven samples of this species have been analyzed for different metals. It is observed that most of the analysed metals are in lower concentration, which are close to or around background values. $\mathrm{Cu}(65$ $160 \mathrm{ppm}), \mathrm{Zn}(8-131 \mathrm{ppm}), \mathrm{Ni}(14-65 \mathrm{ppm})$ and $\mathrm{Co}(0-64 \mathrm{ppm})$ are in lower concentrations. $\mathrm{Cr}(14-162 \mathrm{ppm})$ and $\mathrm{Mn}(819-5513 \mathrm{ppm})$ show slightly higher to moderate concentrations. Very high As content is noticed in soils where Leucas ciliata is grown, but its uptake appears to be poor (10 - $62 \mathrm{ppm})$. Arsenic being an essential element for plants and sometimes toxic, it is likely that it is poorly up-taken by this species.

\subsection{Dodonaea viscosa}

It is quite denser in its occurrence, as it is a drought-resistant shrub, which can thrive even in extreme conditions. No significant morphological change could be observed in this flora. Seven analyzed samples of this species showed poor concentration of $\mathrm{Cu}(110-180 \mathrm{ppm}), \mathrm{Zn}(73-149 \mathrm{ppm}), \mathrm{Ni}(25-170 \mathrm{ppm})$ and Co (10 - $36 \mathrm{ppm})$. Mn is highly variable, as low as 765 to as high $1243 \mathrm{ppm}$ (but, this variation is within the background range). Arsenic concentration of $1-9 \mathrm{ppm}$ is noticed. Fairly higher $\mathrm{Cr}$ is noticed in soils at the sites where this species is thriving, but in the analyzed samples of Dodonea viscosa, its content is lesser (15 - $87 \mathrm{ppm})$. Mn content is higher than in soils.

\subsection{Acacia megaladena}

It is a tree species (Figure 6) growing to a modest height and is present in all the studied lateritic soils in Nayakarahalli, Jaderi and Holur. The metal up-take ability of this species seem to be high for $\mathrm{Cr}, \mathrm{Ni}$ and $\mathrm{Co}$, as they are in higher than background concentration, though they are much lower in comparison to their 


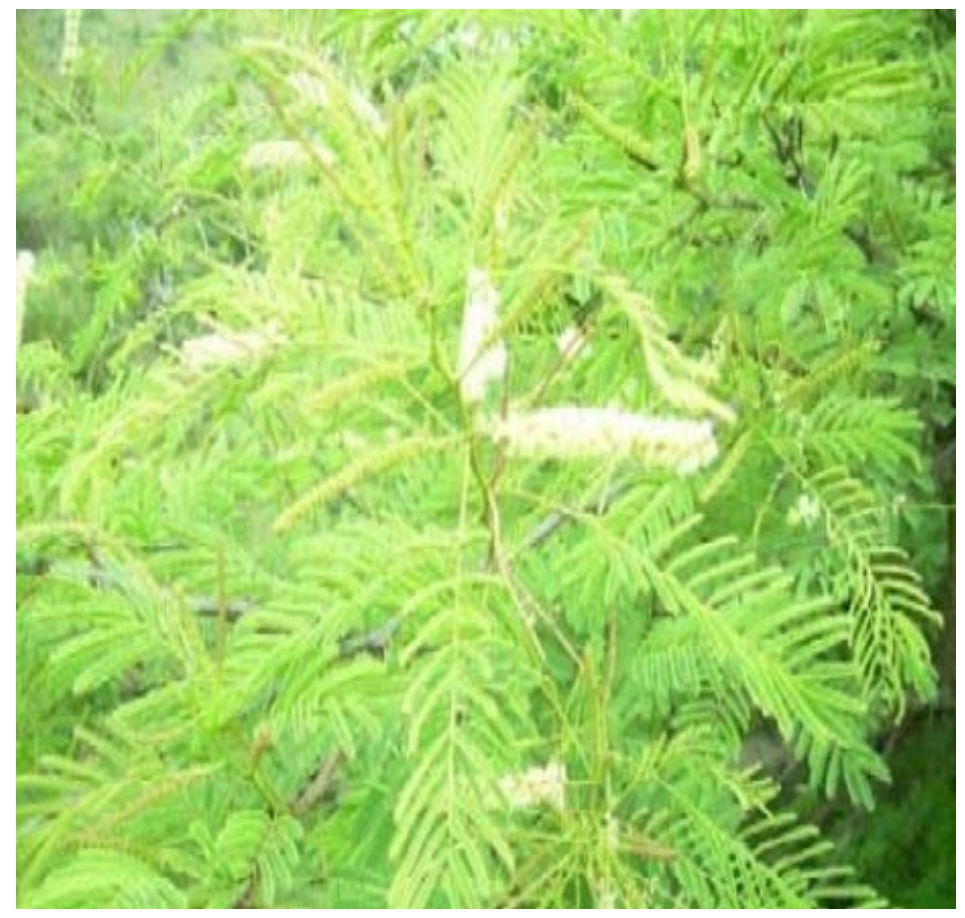

Figure 6. Acacia megaladena near Nayakarahalli area.

concentration in soil. Only two of the six samples showed small concentrations of $\mathrm{Zn}$ (64 - 72 ppm), $\mathrm{Cu}$ (0 - 110 ppm) and Mn (292 - 7879 ppm). Arsenic shows poor to moderate content from 3 to $9 \mathrm{ppm}$.

\subsection{Carissa carandas}

This shrub (Figure 7) occurs in the entire studied area. It has fairly good distribution. It is a perennial species which grows up to $2 \mathrm{ft}$. Its leaves are simple, ovate and shining, with long thorns and it bears terminal inflorescence. In the present study, 4 samples from Nayakarahalli and one from Holur lateritic profiles have been collected. This species is found to exhibit normal growth without any significant morphological changes. From the point of metal accumulation, this species shows variable $\mathrm{Cu}$ content $(0-130 \mathrm{ppm})$, moderate enrichment of $\mathrm{Cr}$ (26 - $74 \mathrm{ppm})$, and lower Zn (84 - 133 ppm), Ni (10 - 25 ppm) and Co (20 $50 \mathrm{ppm}$ ). $\mathrm{Mn}$ is in moderate concentrations. Though arsenic values are lower (20 - 58 ppm), they are slightly above the background concentration. As such, this species does not show any preferential accumulation for any element.

\subsection{Tephrosia tinctoria}

It is a perennial shrub which shows fair distribution in the study area. This shrub grows to a height of 4 - $5 \mathrm{ft}$. Its leaf pattern is alternate. Four samples of this species from Nayakarahalli and two from Jaderi have been analyzed for their trace element content. $\mathrm{Cu}$ shows poorer and variable $(0-180 \mathrm{ppm})$ values. $\mathrm{Zn}$ is almost absent in all the samples. No significant concentration for $\mathrm{Cr}, \mathrm{Ni}$ and $\mathrm{Co}$ is observed. $\mathrm{Mn}$ is in the background range. Arsenic concentration is very poor (6 - 


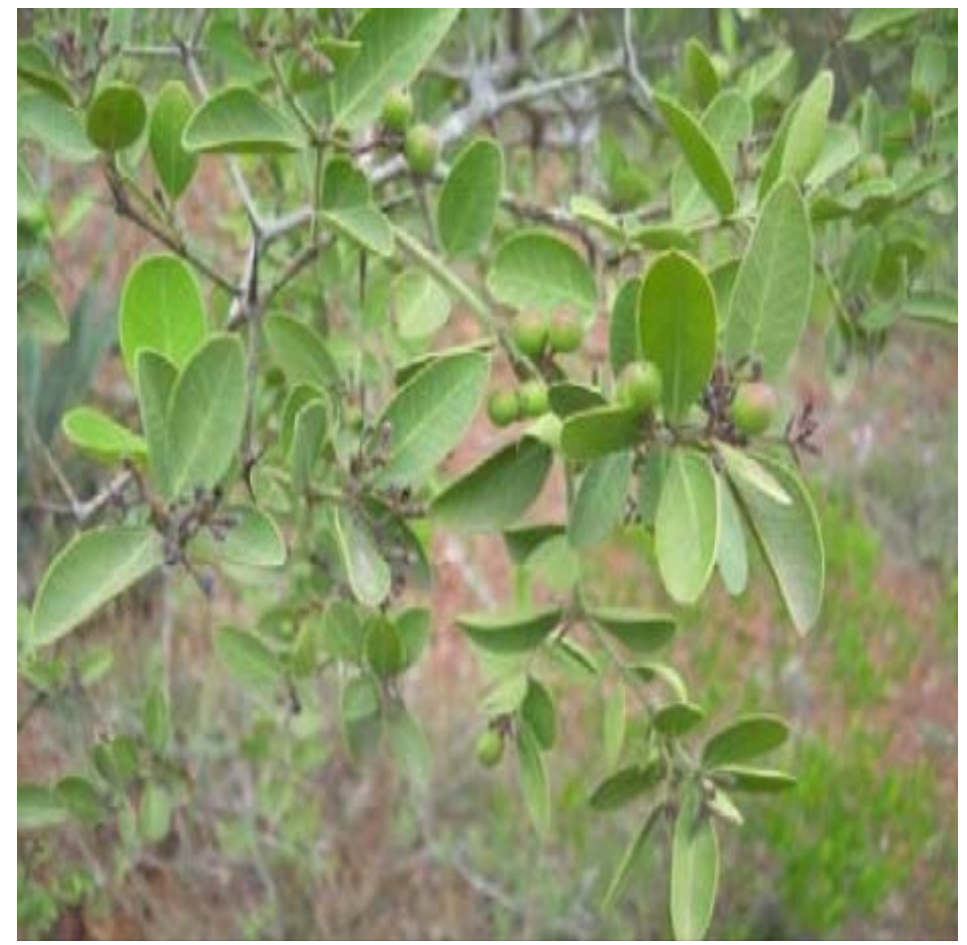

Figure 7. Carissa carandus in Holur area.

$44 \mathrm{ppm}$ ), when compared to significant higher concentration of the same in soil. The metal uptake by this species is not well reflected compared to concentration of metals in soil.

\subsection{Barleria buxifolia}

Most part of the studied Nayakarahalli, Holur and Jaderi areas witness the growth of this plant. This perennial shrub (Figure 8) grows up to a height of 5 $6 \mathrm{ft}$. It shows strong spines under the leaves which are ovate, and bears terminal inflorescence, and flowers are purple-blue in colour. Its growth features and morphological characteristics are normal and lateritic substratum does not seem to have any visible influence on this species. Its uptake ability of metals seem to be modest, like other floral species of the area. It has poor concentration of $\mathrm{Cu}(0$ 150 ppm), Cr (8 - 86 ppm), Zn (0 - 115 ppm), Ni (12 - 40 ppm) and Co (10 - 33 $\mathrm{ppm})$. When compared to their concentration in soils, all of these metals are poorly reflected. $\mathrm{Mn}$ is fairly high in concentration and is comparable to soil concentrations. Arsenic content is very low, close to the background range.

\subsection{Ziziphus Species}

This species does not find homogenous distribution in the studied area. It is a spiny perennial shrub growing to a height of 5 to $6 \mathrm{ft}$ with alternate leaves. Three species of this plant, one from Nayakarahalli and 2 from Holur have been sampled which show lower concentration of $\mathrm{Cu}$ (35 - $90 \mathrm{ppm}), \mathrm{Zn}(0$ - $115 \mathrm{ppm}), \mathrm{Ni}$ (14 - $62 \mathrm{ppm})$, Co (12.16 ppm) and As (13 - $34 \mathrm{ppm})$. Higher concentrations of 


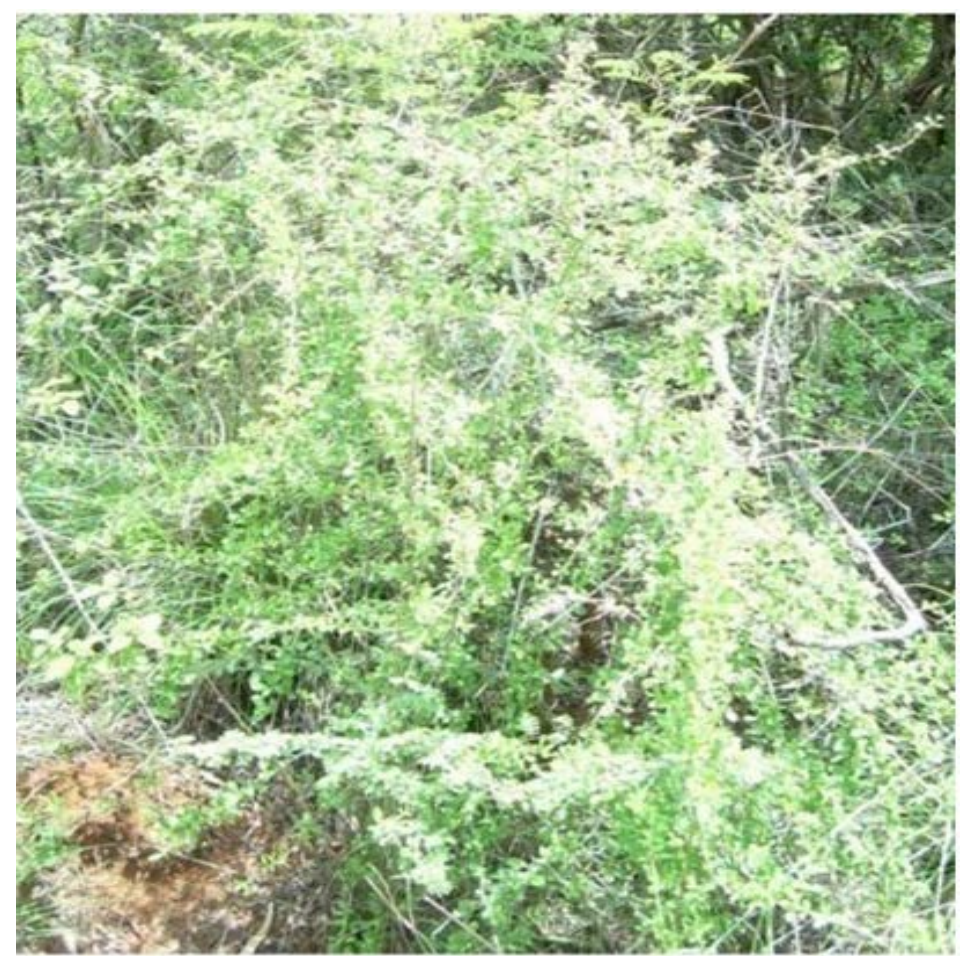

Figure 8. Barleria buxifolia in Nayakarahalli area.

Mn (8116 - 17,271 ppm) is also reflected in this species.

\subsection{Waltheria indica}

This flora is noticed in the entire studied area but with less frequency. This shrub which grows to a height of $6 \mathrm{ft}$ bears yellow flowers in the nodes. A sample each from Nayakarahalli, Holur and Jaderi have been analyzed and the analysis indicate very poor uptake of $\mathrm{Cu}(0-130 \mathrm{ppm})$, Co (12 - $20 \mathrm{ppm}), \mathrm{Zn}$ (15 - 339 ppm), Cr (34 - 86 ppm), Ni (15 - 42 ppm) and Mn (1152 - 3240 ppm). Arsenic values (13-23 ppm) are also around the background concentration. For most of the analyzed elements, soil concentrations are not well reflected in the plant species.

\subsection{Trichodesma indicum}

It is a perennial herb which shows fairly good distribution in Nayakarahalli and Jaderi areas. This herb grows to a height of $3 \mathrm{ft}$. From the point of metal up-take it is poor in $\mathrm{Cu}(0-130 \mathrm{ppm})$ and $\mathrm{Co}(10-16 \mathrm{ppm})$. Arsenic is also poorly concentrated (22-24 ppm). Mn is close to or less than the background range. Except for $\mathrm{Zn}$ and to some content $\mathrm{Mn}$, no other metal is enriched in comparison to soil concentration.

\subsection{Argyreia cuneata}

This species thrives well around Nayakarahalli. It is a perennial shrub (Figure 9) and has lesser density of distribution. Its leaves are oblong and blunt. Bright 


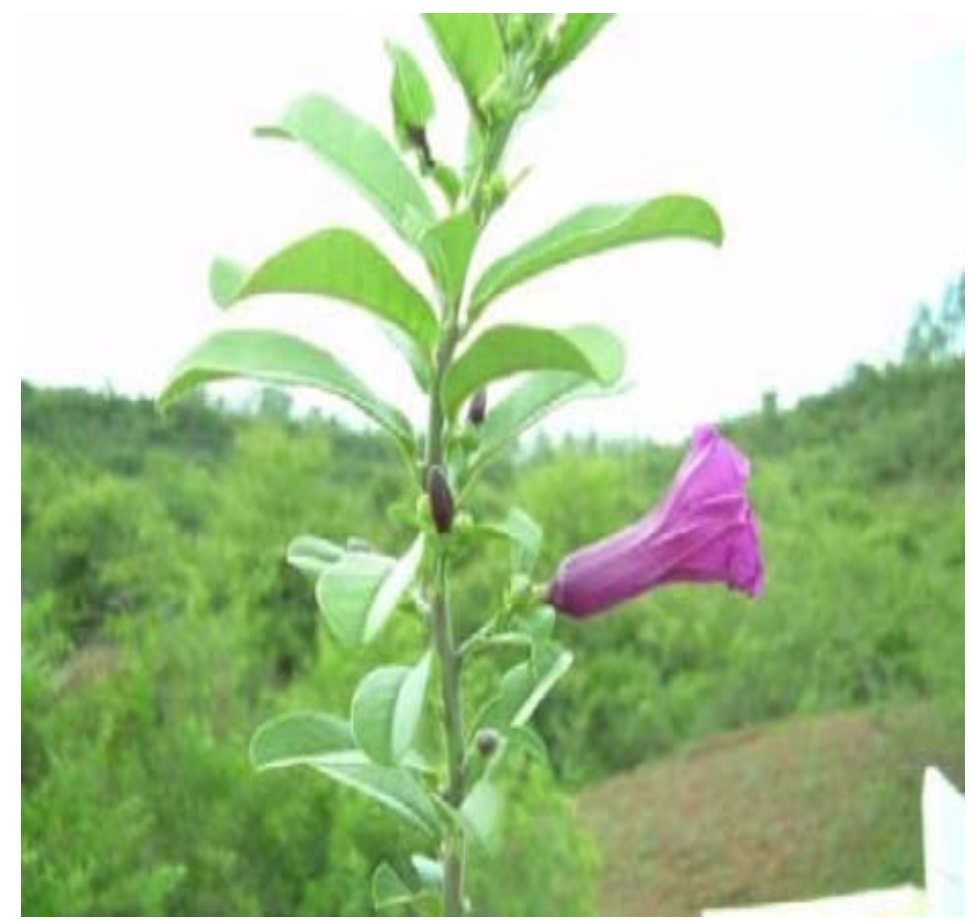

Figure 9. Argyreia cuneata in Nayakarahalli area.

purple coloured and funnel shaped flowers and soft silky haired stems are the characteristic features of this plant. Two samples of this flora around Nayakarahalli have been analyzed and found to contain moderate to poor $\mathrm{Cu}$ (85 - 100 ppm), Zn (0 - 60 ppm), Ni (30 - 40 ppm) and Co (18 - 20 ppm). Cr concentration is slightly higher than background range. Arsenic is also in small concentration (24- $28 \mathrm{ppm}$ ). Mn content is relatively higher, but much lesser than background range.

\subsection{Atylosia scarbiocides}

It has a thin density of distribution and is noticed only in Nayakarahalli and Jaderi. It is a annual/perennial shrub which grows to a height of $2-3 \mathrm{ft}$. It bears alternative triplets type leaves and inflorescence. Samples from both these areas show near background values of $\mathrm{Cu}(120-140 \mathrm{ppm}), \mathrm{Ni}(10-45 \mathrm{ppm})$ and $\mathrm{Co}$ (10 - 13 ppm). A sample from Jaderi has showed slightly higher Zn (569 ppm), whereas the other from Nayakarahalli showed zero value. Arsenic was also zero in Nayakarahalli, but the other sample showed $2 \mathrm{ppm}$. Mn concentration is in the background range.

\subsection{Pavonia zeylanica}

In Nayakarahalli and Jaderi areas, this plant is infrequently noticed. It is a perennial herb (Figure 10) which normally attains a height of $3 \mathrm{ft}$. It is characterized by ovate type leaves, palmately veined with axillary type inflorescence. A sample from Nayakarahalli and another from Jaderi have been analyzed for different metals, and the data shows that it is poor in $\mathrm{Cu}(90-100 \mathrm{ppm})$ and $\mathrm{Ni}(16$ - 


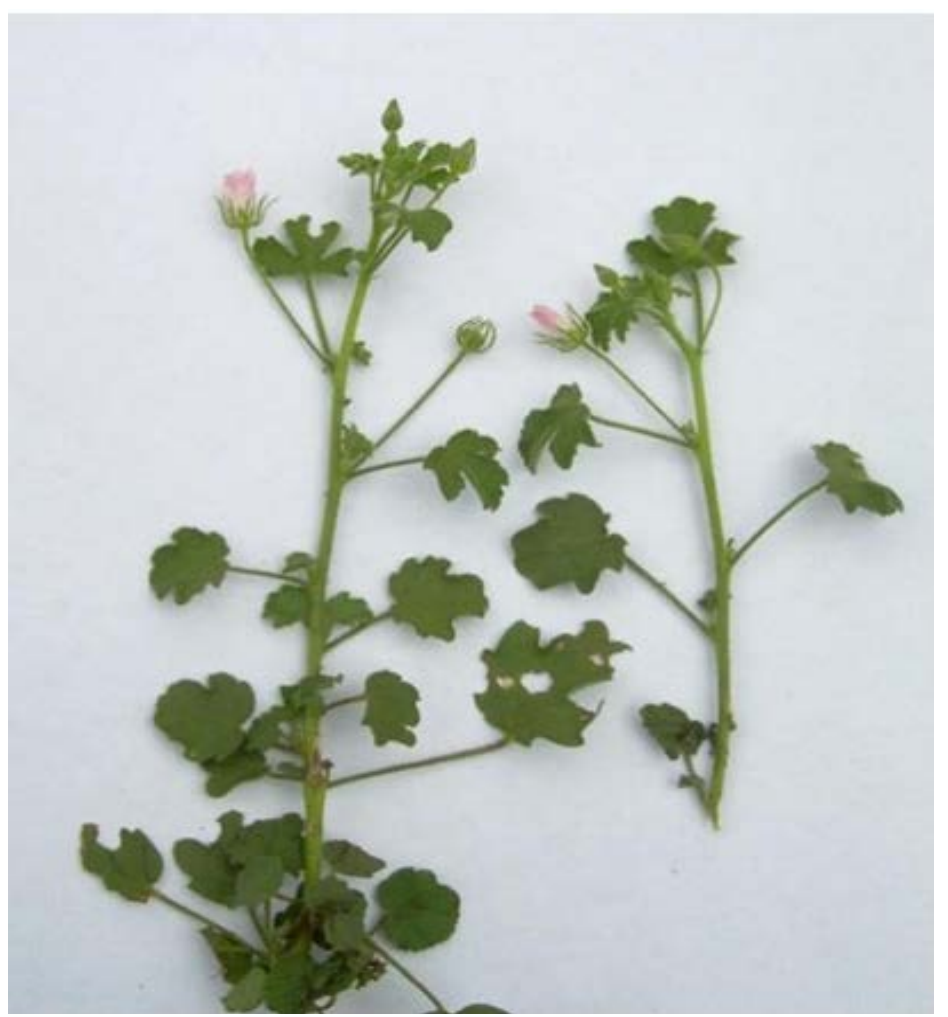

Figure 10. Pavonia zeylanica in Jaderi area.

$18 \mathrm{ppm}) . \mathrm{Zn}$ is slightly higher (131 - $576 \mathrm{ppm}$ ) but still within the background range and Co is in moderate to slightly higher concentration (13-24 ppm). Mn has appreciable concentration. Arsenic is also very poor in concentration (6 - 21 $\mathrm{ppm})$. This plant does not reflect proportionate concentration of metals when compared to metal abundance of soil.

\subsection{Hyptis suaveolens}

Infrequent occurrence of this species is noticed only in Jaderi area. Two samples of this species showed poor concentration of $\mathrm{Cu}$ (135 - $140 \mathrm{ppm}), \mathrm{Cr}(26-45$ ppm), As (13 - $18 \mathrm{ppm})$ and $\mathrm{Zn}(0-223 \mathrm{ppm})$. Ni (30 - $34 \mathrm{ppm})$ and Co (17 - 20 $\mathrm{ppm})$ also showed poor values. Mn values are below the background range.

\subsection{Grass}

A grass variety is commonly noticed in Nayakarahalli area. It blankets the surface in a patchy manner. No significant grass cover is evident in Jaderi and Holur. In the present study four grass samples from Nayakarahalli have been analyzed. All the metals appear to be depleted in the analyzed samples. Chromium showed slightly enhanced values (32-225 ppm) and Mn was close to or slightly enriched than background concentration.

Besides the above floral species which have specific distribution pattern, there are some random species that grow in the studied areas. They included Pulicaria wightiana, Pulicaria wightiana, Chromolaena odorata, Dolichandrone atrovirens 
Stylosanthes fruticosa, Evoluvus alsinoides and Orthosiphon diffusus. A sample of each of these species have been analyzed (Table 1), but no significant metal uptake or depletion in them is noticed, when they are compared with the metal concentration in other species of the studied areas. They do not either reflect the proportionate concentration of metal as compared with the soil substratum (Table 2).

\section{Gold Concentration in Plant Species Growing over Lateritic Profiles of Nayakarahalli, Holur and Jaderi}

As mentioned earlier, the stream sediments in the small rivulets draining the laterite profiles in the study area are known to yield Au fines and small nuggets, which indicated at the laterite-hosted gold which was either in cherty veins or released into lateritic substratum from bedrocks i.e. pillowed metabasalt. Limited analysis of $\mathrm{Au}$ has been carried out for a few plant and soil samples. Herb species like Leucas ciliata (2 samples), Hyptis suaveolens (2 sample), Pulicaria wightiana (1 sample), Tephrosia tinctoria (1 sample) and a tree species viz. like Dolichandrone atrovirens ( 1 sample) have been analyzed and the data is presented in (Table 3). Three soil samples have also been analyzed. The soil analysis showed very poor concentration ( $5-10 \mathrm{ppb})$ of Au. Though these values are slightly higher than the background, no appreciable enrichment could be deciphered. Contrary to this, plants have a fairly high concentration of Au. Leucas ciliata showed 37 and $83 \mathrm{ppb}$, Hyptis suaveolens 25 and $36 \mathrm{ppb}$, Tephrosia $86 \mathrm{ppb}, \mathrm{Pu}$ licaria wightiana $25 \mathrm{ppb}$ and Dolichandrone atrovirens $68 \mathrm{ppb}$ (Table 3). These values probably suggest that $\mathrm{Au}$ in soil was available in the form of humic salts, which enabled plants to up-take it. Compared to background of $5 \mathrm{ppb}$ concentration level in plants, these values are very high, which suggested that the plants growing over lateritic substratum could able to effectively uptake it and this aptly reflected the auriferous nature of the area.

\section{Discussion and Conclusions}

Lateritic zones overlying metabasaltic bedrocks in the southern parts of Srinivaspura i.e. Holur-Nayakarahalli-Jaderi constitute distinct terrain conditions for geobotanical and biogeochemical studies. A general flat nature of this terrain

Table 3. Au concentration (in ppb) in plants and soil.

\begin{tabular}{ccc}
\hline Plant species & Con. in plants & Con. in soils \\
\hline Leucas ciliata & 37 & 6 \\
Leucas ciliata & 83 & 10 \\
Hyptis suaveolens & 36 & 5 \\
Hyptis suaveolens & 25 & - \\
Tephrosia tinctoria & 86 & - \\
Pulicaria wightiana & 25 & - \\
Dolichandrone atrovirens & 68 & - \\
\hline
\end{tabular}


and moderate drainage pattern constitute a plateau like landscape. Dispersion of metals in this type of conditions could be controlled/affected by 1) enrichment of certain elements and draining out of some during lateratization, 2) dispersion of metals from the underlying metabasalts by hydromorphic process and 3) dispersion of elements from the cherty horizons (which normally resist lateritization due to their high silica nature) by oxidation and gossanisation process. The geochemical characteristics at the metabasalt-laterite interface are expected to be more or less the same and the dispersion pattern would be more homogeneous, barring localized variations. But considering the spatial distribution, the lateritized zones have vast spatial extent compared to cherty horizons. This setting could promote variable metal dispersion especially from the point of gold and other chalcophile elements. However, distribution of elements in drainage sediments could have been affected by mixing process and obviously are normalized. Hence, it becomes difficult to appraise the dispersion pattern of $\mathrm{Au}$ from the point of their concentrations in drainage sediments, i.e. whether Au has been derived from lateritized soil or cherty intercalations. However, elements like $\mathrm{Cu}$, $\mathrm{Cr}, \mathrm{Ni}, \mathrm{Co}$, As and Mn contents form more homogenous pattern, because of the homogenous substratum and bedrock conditions (Figure 11). All the metals mentioned above are fairly in good concentrations in soil, except few samples. Some of the relatively soluble elements like $\mathrm{Cu}$ and $\mathrm{Co}$ could have also been drained during lateritization. Uptaking by plants of most of the metals like $\mathrm{Cr}$, $\mathrm{Ni}, \mathrm{Co}$, As and $\mathrm{Mn}$ reflect that these elements existed in soil substratum mostly as oxides as these metals are susceptible for oxidation during their prolonged
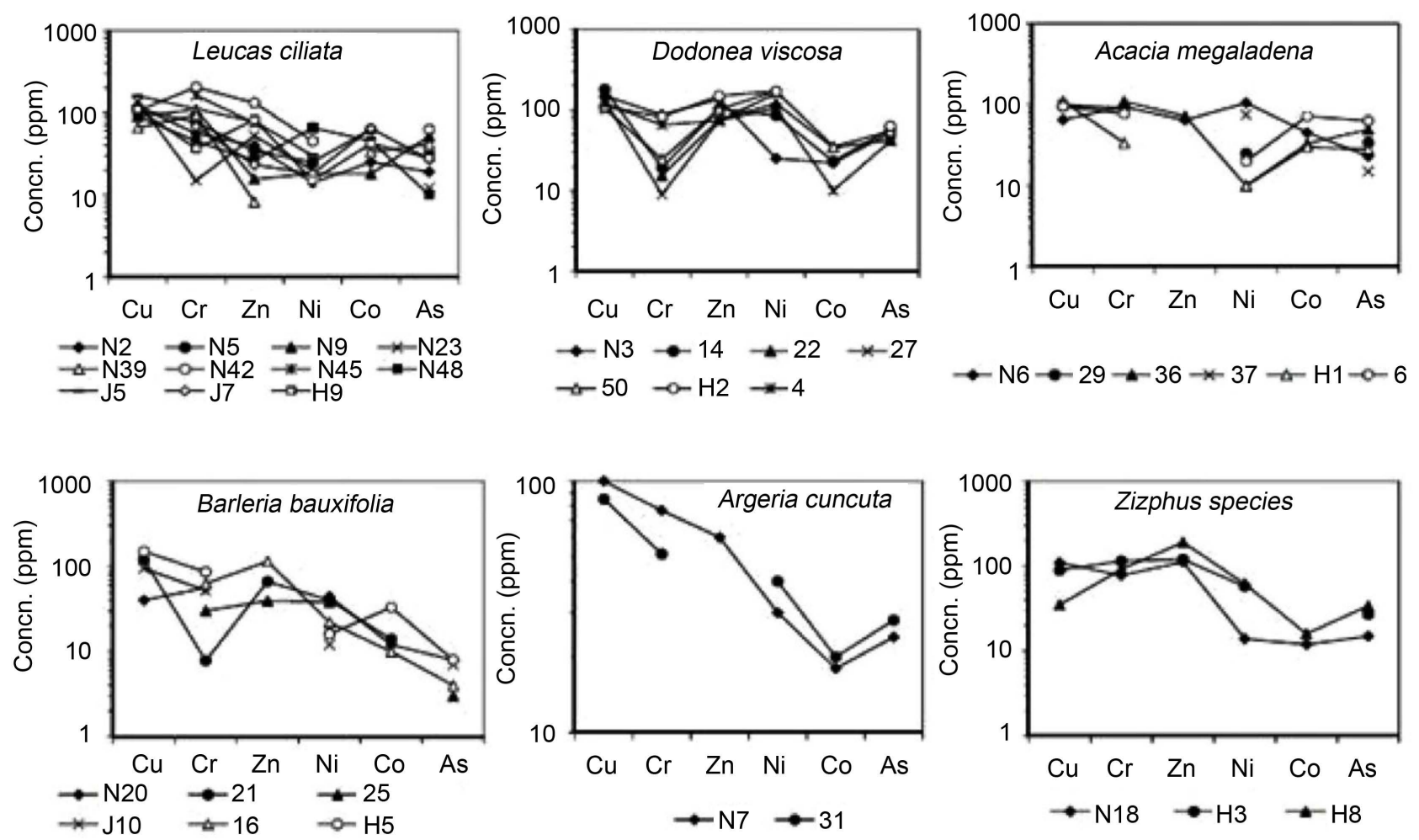

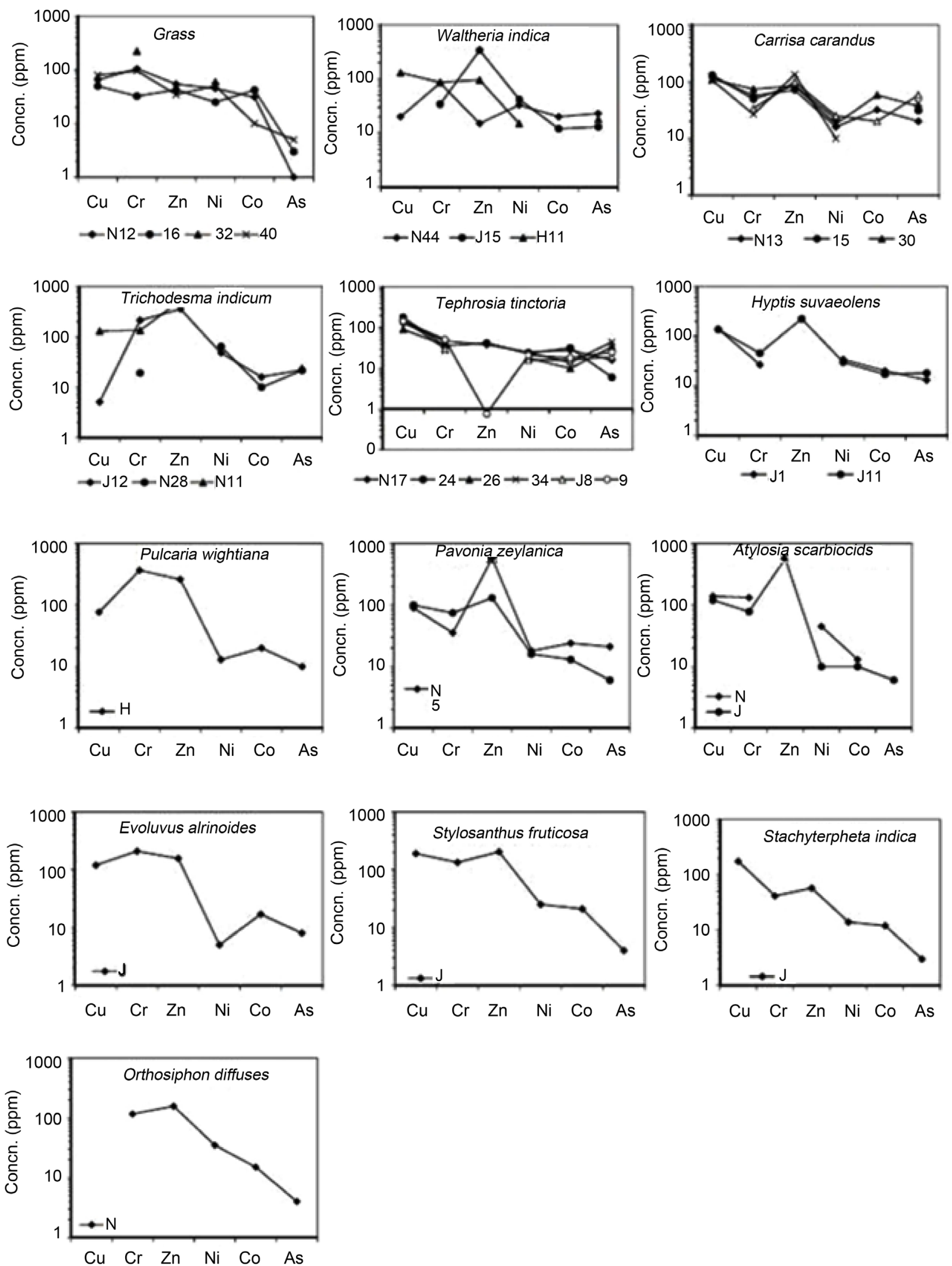

Figure 11. Trace element values plotted for studied plant species. 
atmospheric exposure. However comparatively lesser values of metals in plants in relation to soil (Figure 12) indicates their poorer uptaking ability, which in turn could have been controlled by many biotic and abiotic factors, besides climatic influences prevailed in the terrain. Exceptionally, some species have absorbed high Mn. Similarly, high value of $\mathrm{Zn}$ seen in Pavonia zeylanica is only an isolated high but not high enough to be anomalous. Almost the background range of $\mathrm{Au}$ as inferred from very limited analysis reflects poor and uneven distribution of this metal in soil. However, plants express Au content in a better way (25 - $86 \mathrm{ppb}$ ). This is because, Au probably existed as colloidal particles adhering to iron hydroxides in soil. Humic acid activity could have influenced to make Au content available as colloidal particles to be present as adsorbed ions around iron oxides. Obviously, an inverse relation of Au concentration could be seen in the study area where poor concentration in soil and high concentration in plant is evident. Further, detailed biogeochemical studies could throw more light into the possible auriferous horizons underneath.

\section{Acknowledgements}

The authors thank Bangalore University for the financial support to carry out this work through a research grant. Mr. R. Nijagunaiah, Department of Botany, Bangalore University is gratefully acknowledged for his help in identifying the plant species both in field and laboratory. Dr. A. K. Roy, Regional Director,
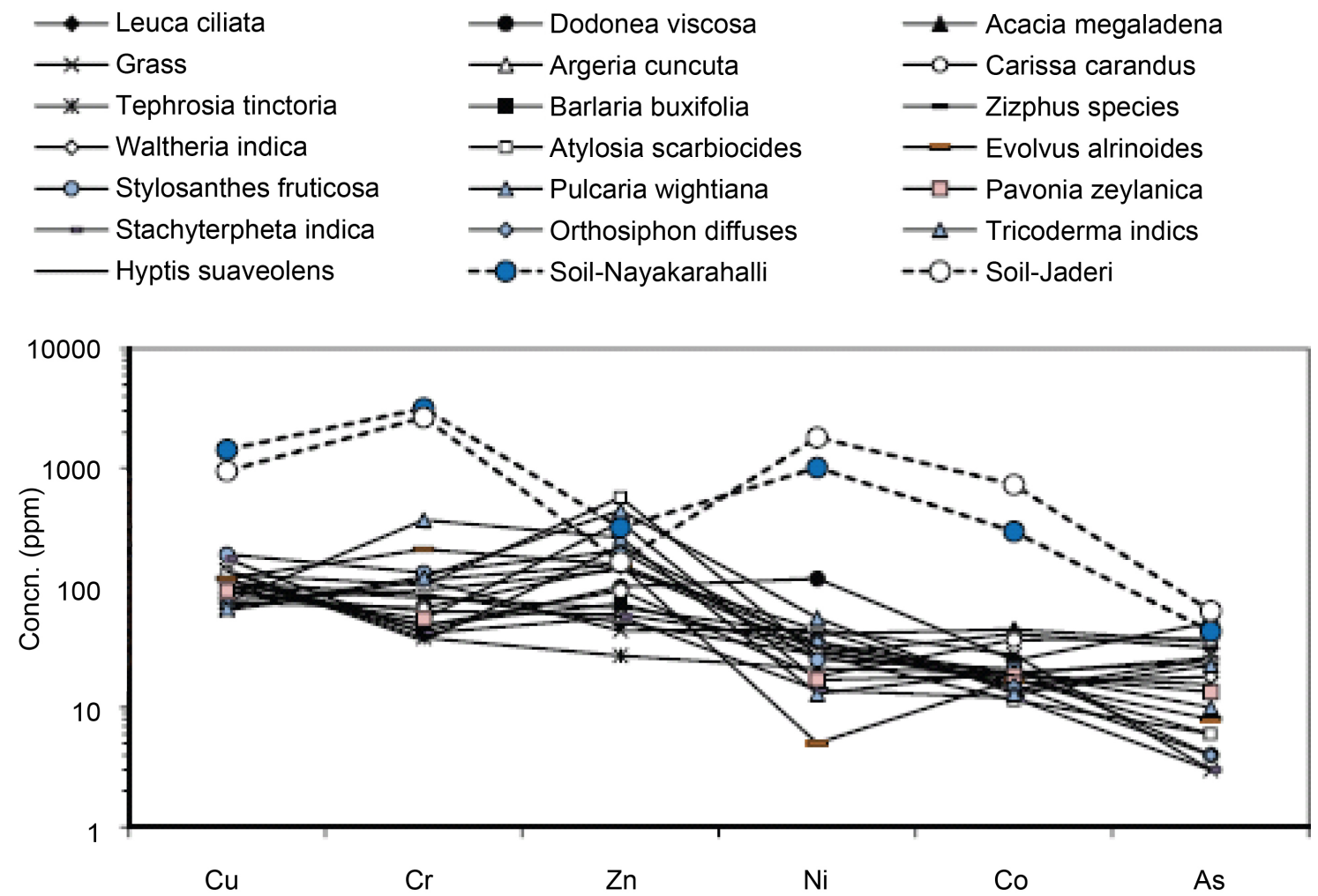

Figure 12. Average metal concentration of plants plotted against average of soil samples. 
and his collegues Dr. Premdas and Dr. Anitha Mary of AMD, Bangalore and Mr. K. B. S. S. Seetharam of M/s Shiva Analyticals Pvt. Ltd., for extending facilities for gold analysis. Mr. S. Santhosh, Ph.D. Scholar in the Department of Geology, Bangalore University is acknowledged for his assistance in preparing figures, tables and graphs.

\section{References}

[1] Sivasiddaih, N. and Rajamani, V. (1989) The Geological Setting, Mineralogy, Geochemistry and Genesis of Gold Deposit in the Archaean Kolar Schist Belt. Economic Geology, 84, 2155-2178.

[2] Narayanaswamy, S., Ziauddin, M. and Ramachandra, A.V. (1960) Structural Control and Localization of Gold Bearing Lode, K.G.F., India. Economic Geology, 55, 1429-1459.

[3] Mukherjee, M.M., (1989) Evolutionary Aspects of Au Mineralization in Southern Part of Kolar Schist Belt. Indian Minerals, 43, 347-360.

[4] Ziauddin, M. and Narayanaswamy (1974) Gold Resources of India, Bull. Geological Survey of India. Economic Geology Series, 38.

[5] Madhusudhanan, R., Venkatasubramanian, M. and Mallikarjuna, C. (1991) Investigation for Gold in Chinmulgund Area, Dharwar District, Karnataka. Rec. Geological Survey of India, 124, 82-84.

[6] Brooks, R.R., (1972) Geobotany and Biogeochemistry in Mineral Exploration, Harper and Row Publishers, 290.

[7] Rashmi, B.N., Prabhakar, B.C., Gireesh, R.V., Ranganath, R.M., Nijagunaiah, R. and Suresh, B. (2010) Geobotanical and Biogeochemical Study of Chromite Bearing Areas of Nuggihalli Schist Belt. Current Science, 99, 619-627.

\section{Scientific Research Publishing}

Submit or recommend next manuscript to SCIRP and we will provide best service for you:

Accepting pre-submission inquiries through Email, Facebook, LinkedIn, Twitter, etc. A wide selection of journals (inclusive of 9 subjects, more than 200 journals)

Providing 24-hour high-quality service

User-friendly online submission system

Fair and swift peer-review system

Efficient typesetting and proofreading procedure

Display of the result of downloads and visits, as well as the number of cited articles

Maximum dissemination of your research work

Submit your manuscript at: http://papersubmission.scirp.org/

Or contact ijg@scirp.org 